de psychologie van de menselijke verhoudingen;

de eigenschappen van de chef;

de taak van de chef;

waarop het bij een chef aankomt;

de betekenis van de toegepaste psychologie voor het bedrijfsleven.

De taal van het boekje is eenvoudig gehouden, terwijl het in een handig formaat is uitgegeven. Het is overzichtelijk en zal iedere directeur, bedrijfsleider, afdelingschef, personeelsfunctionaris en opzichter waardevolle richtlijnen geven.

Ir. F. J. Philips, die verschillende van zijn medewerkers tot deze goede vertaling en bewerking inspireerde, noemt in zijn inleiding Carrard's boek een bijdrage voor alle chefs, die hun wijze van samenwerken willen baseren op de grondslagen van het christendom en van algemene menselijke waarden.

Ook uit dit oogpunt verdient het werkje alle aandacht.

\title{
MEDEDELING VAN DE VEREENIGING VAN ACADEMISCH GE- VORMDE ACCOUNTANTS
}

In de Buitengewone Ledenvergadering van de Vereeniging van Academisch Gevormde Accountants, gehouden op 23 April j.l. te 's-Gravenhage, werden tot lid benoemd de Heren Dri A. Kauer te 's-Gravenhage, F. P. J. Bakx te Tilburg, W. Zuurmond te Zwolle en E. B. Ceelaert te Rotterdam.

In dezelfde vergadering werd het ere-lidmaatschap aangeboden aan Dr G. J. L. Brackel, mede-oprichter van de Vereniging en Oud-Voorzitter.

\section{REPERTORIUM VAN LITERATUUR OP HET GEBIED VAN ACCOUNTANCY EN BEDRIJFSHUISHOUDKUNDE}

Redactie: Stichting Centrale Dienst voor Bedrijfsdocumentatie

\section{TIJDSCHRIFTENREPERTORIUM}

\section{A. ACCOUNTANCY}

\section{LEER VAN DE INRICHTING}

De administratie en de efficiency in de detailhandel.

J o n $\mathrm{g} \mathrm{m}$ a n, C. D. In het voorgaande artikel werd de oplossing van het vraagstuk van het uniforme boekhoudschema van belang geacht én voor de detaillisten én voor het samenstellen van bedrijfsstatistieken. Schr. behandelt in dit artikel de eisen welke aan het rekeningschema gesteld moeten worden. Schr. behandelt achtereenvolgens: De geldadministratie; het kasboek; de kostensplitsing; de crediteuren- en debiteurenadministratie; de administratie van het goederenbeheer; de omzetspecificatie.

A III 2 Tijdschrift voor Interne Bedrijfsorganisatie Jrg. 3, No. 2, Februari 1948

m a b blz. 160 


\section{Dossiervorming en dossierordening}

Redactie - Nadere uiteenzetting van het begrip "dossiers". Dossiervorming dient te zijn gebaseerd op een goed inzicht in de criteria der bijzondere classificatie van het administrerend orgaan. Dit inzicht moet in de dynamische periode worden gevormd om degenen, die in de statische periode het dossier raadplegen, een duidelijk inzicht te geven in de handelingen der dossiervormende instantie. (eerste van een serie artikelen) A III 3

Overheidsdocumentatie, Jaarg. 2, No. 4, April 1948

\section{B. BEDRIJFSHUISHOUDKUNDE}

\section{a. ALGEMENE BEDRIJESHUISHOUDKUNDE}

\section{WAARNEMINGSMIDDELEN}

\section{Order-billing plan aids management}

Ne um a i er, R. - Prescription of a newly installed simplified order- and billingprocedure of the Pensylvania Salt Manufacturing Co. It furnishes information to prepare every thing from salesmen commission reports to local advertisingexpenditures. Summing up of the seven reports and records, which can be prepared from detailcards.

B a III 3

American Business, Februari 1948

\section{Einige Probleme der Kostentheorie}

B or owski, R. - Kosten werden von der Unternehmung nur für einen dadurch zu erziehlenden Ertrag aufgewendet. Sie werden in den folgenden Ausführungen nicht im Hinblick auf ihren Zusammenhang mit der Produktion sondern mit der Ertragserziehlung untersucht. Dabei ergibt sich eine Einteilung in: Kosten der Ertragsmöglichkeit, Kosten der Stückerträge; Kosten der Perioden-Erträge. Das Unternehmungsrisico wird durch die Kosten der Ertragsmöglichkeit verursacht. Anschliessend wird untersucht welche Folgerungen für die Verrechnung der Kostten sich aus dieser Betrachtungsweise ergeben.

B a IV 2a

Industrielle Organisation, Jaarg. 17, No. 1, 1948

The figures are ready every day.

Editor - Very short description of the production of costs- and salesfigures by day as maintained by the Chicago Steel Service Company. 4 photographs and 1 fig. B a IV $2 b$

American Business, Vo. 18, No. 4, April 1948

\section{Toepassing der belastingwetten}

A d ri ani, P. J. A. - Korte, heldere, belangwekkende uiteenzetting aan de hand van de laatste arresten aangaande inkomsten-, vermogens-, en ondernemersbelasting ten aanzien van bedrijfs en particulier vermogen. Wat is te verstaan onder bedrijf. Hoe rekent de fiscus bij overgang der vermogensbestanddelen naar privé en omgekecrd? Wat is bedrijfs-, wat is particulier vermogen. Wat is het gedag van de fiscus ten aanzien van de bij liquidatie vrijkomende reserves? (Met vermelding van de arrestnummers en data)

B a IV 2e Weekblad voor privaatrecht, notaris-ambt en registratie Jaarg. 7, No. 4023, 28 Februari 1948

\section{Berekeningen bij goodwill.}

Andriesse, G. - Berekeningsmethoden voor de bepaling van de goodwill. Deze wordt hier uitgevoerd ter bepaling van de uitkoopsom $=$ gekapitaliseerde basiswinst, vermenigvuldigd met een correctiefactor, die afhankelijk is van het aantal toekomstige winsten, het toekomstig verloop van deze winsten en de rentevoet. Schr. is een voorstander van het in de berekening betrekken van, zowel de economische als de technische levensduur der te berekenen waarden. Voorts wordt gegeven een model van een afschrijvingsplan voor de goodwill. ( 5 grafieken, 3 tabellen)

B a IV 6 De Naamloze Vennootschap. Jaargang 25, No. 11, Februari 1948

m a b blz, 161 


\section{De ondernemersbelasting als last van het jaar waarover zij wordt berekend}

Hendriks, H. E. F. - Schr. geeft een methode om de ondernemersbelasting ten laste te brengen van het jaar, waarover zij wordt berekend. Dit zal volgens het betoog voornamelijk ten voordele zijn voor die ondernemingen die in opeenvolgende jaren belangrijke winstfluctuaties kennen. (In een redactionele noot wordt nagegaan, in hoeverre de belastingautoriteiten deze berekeningswijze zullen accepteren).

B a IV 7

Maandblad voor Belastingrecht, Jaarg. 16, No. 5, Maart 1948

\section{LEER VAN DE FINANCIERING}

Baas in eigen huis

Schling e ma nn. J. G. - Door belastingpolitiek tot uitgangspunt der financieringspolitiek te maken dus vorming van overgrote stille reserves - zijn de aandelen van de eenmans- en familie vennootschappen op de aandelenmarkt ondergewaardeerd. Door hoge kapitaaleisen is interne financiering vaak niet meer mogelijk. Bij de emissie zou openbaarmaking der werkelijke toestand nodig zijn en krijgt men te doen met de heffing der vermogensaanwas, of, indien slechts een gedeelte der stillen reserves zou worden geopenbaard, geeft men aan de nieuwe aandeelhouders een deel der stille reserves. Preferente aandelen zijn niet en vogue. Tracht men onderhands kapitaal te verkrijgen dan verliest men een groot deel van de zeggenschap over zijn bedrijf. Schr. verdedigt tegenover de fiscale overheid uitzonderingstarieven voor dergelijke ondernemingen.

B a V 5d Economisch Statistische Berichten, Jaarg. 33, No. 1610, 17 Maart 1948

Les risques dans l'entreprise privée.

Urbain Vaes - Etude des causes générales des risques. Causes naturelles. Causes humaine d'ordre physiologiques, d'opposition d'interêtes, de déficiennes de l'organisation économique générale comme les risques de conjoncture et les risques monetaires, de progres de la science et de l'état de population, d'insuffisance de l'organisation interne. Classification des risques selon leurs caracteristiques suivie par un bref examen de leurs localisation. Résumé sommaire de moyens générales employés pour combattre les risques; dispositions preventives, mesures éclairants et de vérification, mesures compensatoires comme l'assurance extérieure et intérieure.

B a V 6 Annales de sciences economiquées. Année 6. No. 1, Februari 1948

\section{LEER VAN DE ORGANISATIE}

\section{Gerichte reclame en haar plaats in het budget}

Kastele in. J. - Doel van de gerichte reclame en dat van alle reclame, n.l. verkopen. Er wordt op gewezen, dat tussen gerichte reclame en andere raclame geen wezenlijke tegenstellingen bestaan. Belangrijkheid van de gerichte reclame ligt in de gerichtheid. Negen punten waarin de karakterverschillen worden aangeduid tussen gerichte en overige reclame. Uitvoerige bespreking dezer punten. Nadere bespreking van de plaats van de gerichte reclame in het budget.

$\mathrm{B}$ a VI 11

Revue der Reclame, Jaarg. 7, No. 10-11, 1947

\section{Het richten der gerichte reclame}

Spruytenburg - Onderscheid wordt gemaakt tussen psychologisch richten en technisch richten. Schr. behandelt eerst de vorm van het psychologisch richten: briefkaart, folder, boek, enz. Wijze van adresseren. De tijd wanneer men de gerichte reclame moet toepassen. Technisch richten: het bezorgen van drukwerk. De mogelijkheid om het geschikte adressenmateriaal te verkrijgen.

$\mathrm{B}$ a VI 11

Revue der Reclame Jaarg. 7, No. 10-11, 1947

\section{The office is management}

Brecht, Robert P. - The office-function is a managementfunction. A critical analyses of the office-function. Elucidation of the idea, that the office exists tot aid production. A questionnary on general problems of officemanagement is added.

B a VI 16

Noma Forum. Vol. XXIII, No. 4, April 1948 


\section{De rechtsverhouding tussen directeur en N.V.}

Kamphuisen, P. W. - Heldere, overzichtelijke behandeling van dit moeilijke onderwerp. Het is voor iedere vennootschapsdirecteur gewenst, aan de hand van het gebodene de bepalingen van het eigen contract nog eens te toetsen. De wet behandelt de directieovereenkomst als arbeidscontract. In feite geeft de wet in art. 43 W.v.K. echter de directie de souvereiniteit in het bedrijf. Gewoonlijk stemmen de bepalingen van het contractueel normencomplex en het objectief vennootschappelijk recht niet geheel overeen, doordat de N.V. in wezen meer is een publiekrechtelijk lichaam dan een privaatrechtelijke overeenkomst. (Uitgebreide literatuuropgaven)

B a VI 16

De Naamloze Vennootschap, Jaarg. 25, No. 11, Februari 1948

\section{Who qualifies for personnel work?}

Ste in met $z, H . C$. - To improve the caliber of personnel workers and to enhance the status of our profession, says Mr. Steinmetz, we must strive to establish standards of professional competence. The author suggests five criteria of competence: an established interest in adjusting others; worthy standing among associates, superiors and subordinates; usefull knowledge of people and of ways and means of dealing with them, plus knowledge of techniques; insight as revealed by prognostic accuracy and clinical adequacy. Readers are urged to apply these tests to themselves as well as to candidates for personnel jobs.

B a VI 16

Personnel, January 1948

\section{A pattern for improved supervisory leadership}

Pfiffner, J. M. - The new pattern of supervisory leadership which is emerging in progressive organisations embraces two-way communication, participation, consultation and ego satisfaction for members of the working group. But while the democratic supervisor is group-minded, he is at the same time a clinician who takes account of individual differences, adopting a fact-finding. case-study approach to personnel problems. He learns to think of people in much the same manner as the social scientist for instance, recognizing "racial" differences as being due to environmental rather than biological factors. This type of leadership can be inculcated at the production level; asserts Dr. Priffner, provided management creates the proper ,social climate" for it. B a VI 16

Personnel, Januarty 1948

\section{Batch Handling by Power and Handtrucks}

Beskine, J. M. (Engl.) - With respect to economical proportionality stress is laid on the consideration of overall handling costs as a criterion for the making of batch handling standards. Some practical ideas are given for outwiping double-handling and unnecessary operator fatique as already practised in Ascot Works. The description is of general interest to similar factories. 7 photographs, 3 schemes showing the savings by the new method in comparison with the old one, 2 figures.

B a VI 18

Mechanical Handling, Vo. 35, No. 5, May 1948

\section{Assembly line methode in the office}

Wells Norris - Describing how Moorman Manufacturing Co. can handle orders from 2.100 salesmen with 275 office employees by the use of thoroughly up-todate administrative machinery in assembly line process. Short description of the machinery in use and its various particular advantages. 6 photographs.

B a VI 19 American Business, Bol. 18, No. 4, April 1948

\section{Organisatie van de inkoop}

Ki eft, J. v. d. - Schr, behandelt de taak van de inkoopafdeling. Er wordt op gewezen, dat deze taak te eng werd gezien. Opsomming van wat de practische uitvoering van de inkooptaak omvat. Plaats van de inkoopafdeling ten opzichte van de andere afdelingen. De wijze van aanvragen en offerte maken. Noodzaak van het schriftelijk bevestigen van de bestellingen. De inkoopafdeling moet tevens de controle over de prijzen hebben. Schr. is van mening dat ook bij de inkoopafdeling de documentatie niet mag ontbreken. Tot slot gaat schr. nog in op het verband met de andere afdelingen en geeft grafische voorstellingen daarbij.

B a VI 22 Tijdschrift voor Interne Bedrijtsorganisatie, Jaarg. 3, No. 2 Februari 1948

m a b blz. 163 


\section{Het vraagstuk der pensioenvoorziening in het particuliere bedrijf}

Algemene beschouwing over de vraag, hoe een eventuele pensioenvoorziening in het particuliere bedrijf dient te worden geregeld. Schr. verwerpt de gedachte van Staatspensioen en ziet hier een taak weggelegd voor de bedrijven zelf.

B a VII 3

De Naamloze Vennootschap, Jaatg. 26, No. 1, April 1948

lets over de sociale en economische zijde van het pensioenfondsvraagstuk

De $\mathrm{R}$ ingh, K. De sociale bestaansgrond van de pensioenfondsen is gelegen in het recht van de werknemer zich en zijn gezin door zijn arbeid levensonderhoud te verzekeren, niet slechts gedurende zijn actieve levensperiode, doch ook daarna.

B a VIII 3 De Naamlooze Vennootschap. Jaarg. 26, No. 1, April 1948

\section{Teaching workers the facts about profits}

Editorial - The scope of this article is to show the manner in which the workers can be made clear the facts about profits. Profits are not always in cash. Workers should be told why en how profits may be wiped out by inventory losses, price decreases or any sort of uncontrolable factors.

B a VII 3

American Business, February 1948

\section{Ban industry wide strikes under anti-trust-laws?}

Hartley, Rep. Fred. A. Jr. and Carmel, Daniel D. - A debate in print from a Republican, co-author of the Taft-Hartley-Act, Rep. Hartley and the former Assistant Attorney General for the state of Illinois, now General Counsel for the American Federation of Labor. Full argument is given from both sides on this important question. Its solution in one or other way may have considerable influence on labor conditions in Europe too.

B a VII 4

Modern industry, Vol. 15, No. 4, April 15, 1948

\section{Twee opmerkingen over tijdsstudies}

Goudria a n, J. - Bij relatief grote variatie-coëfficiënt van de arbeidsduur zal het uitbetaalde loon vele procenten kunnen afwijken van een op basis van het rekenkundig gemiddelde gebaseerde berekening. Het gebruik van harmonische gemiddelden is hier de enige oplossing. Schr. geeft de formule voor het harmonisch gemiddelde en tevens een bruikbare benaderingsformule. De studie van de variatiecoëfficiënten der verschillende soorten arbeid staat nog in de kinderschoenen. (Literatuuropgave).

B a VII 5 Tijdschrift voor Efficiency en Documentatie, Jaarg. 18. No. 3, Maart 1948

La technique de l'emploi de la musique dans les bureanx

Goldsmith, Dorothy - L'usage de la musique, sous l'une ou l'autre forme, dans le but de rendre le travail plus agréable et plus reposant, est une pratique presqu'aussi vieille que la civilisation elle-même.

B a VII 5

Bureau Magazine, No. 3, Mars 1948

Vermocidheid bij machinewerk

S p a a n, J. B. J. - Schr. wijst op het veelvuldig voorkomen van vermoeidheid bij het werken met schrijf- of boekhoudmachines. Oorzaken van deze vermoeidheid worden aangegeven, en mogelijkheden besproken om de vermoeidheid te beperken.

B a VII 5

Het modcrne Bedrijfsleven, April 1948

Why do employees quit?

Douglas Jack, W. - Short discussion of the reason why employees may quit and how to stop this effectively.

B a VII 8

Noma Forum, Vol. XXIII. No. 5, May 1948 